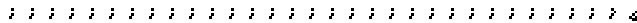

: Widya Akuntansi dan Keuangan

\title{
PENGUKURAN KINERJA KEUANGAN PEMERINTAH KOTA PONTIANAK
}

\author{
Akhmad Yani ${ }^{1}$ \\ Zulkarnain Zulkarnain ${ }^{2}$ \\ ${ }^{1,2}$ Program Studi Akuntansi, Institut Manajemen Wiyata Indonesia \\ Email Korespondensi: zulkarnain@imwi.ac.id
}

\begin{abstract}
Demands on performance and the implementation of the principle of performance accountability lead to the need to measure local government performance. Performance measurement is important to assess the accountability of officials or organizations in producing the best service to the public, as well as in realizing good governance in local governments. This study seeks to provide an overview of the financial performance of the Pontianak City Government by using performance measurement tools in the form of regional financial ratios. Quantitative approaches are used in data analysis. The narrative form is then descriptively applied to illustrate the findings from the results of the analysis of related data. From this research it was found that the Pontianak City Government is quite capable in financing the administration and development in the regions; PAD revenues increase from year to year; the contribution of local taxes is very large in the formation of overall PAD; dependence on transfers from the central and other regional governments, including the category of "medium"; achieving the PAD target is classified as very effective; and the capital expenditure ratio has exceeded the average capital expenditure ratio in regional governments.
\end{abstract}

Keywords: Regional Financial Performance; Financial Ratio Analysis; Pontianak City.

\section{PENDAHULUAN}

Sejak diberlakukannya Undang-Undang tentang Otonomi Daerah paska reformasi tahun 1997, setiap Pemerintah Daerah (selanjutnya disebut pemda) dituntut untuk menjalankan roda pemerintahan dengan efektif dan efisien, serta mampu memberikan hasil (kinerja) yang baik dalam persoalan kemajuan tingkat ekonomi, kualitas SDM, dan pengelolaan kekayaan sumber daya alam. Tuntutan tersebut untuk menjadikan masyarakat lebih sejahtera dan IPM (Indeks Pembangunan Manusia) juga meningkat (Novitasari \& Hapitri, 2019).

Pola desentralisasi dengan banyaknya wewenang yang dilimpahkan dari pemerintah pusat ke daerah menuntut good governance di daerah. Setiap kegiatan dan outcomes (hasil akhir) kegiatan yang diselenggarakan oleh pemerintah daerah harus dapat dipertanggungjawabkan, baik kepada publik maupun kepada pemerintah pusat, sebagai bentuk pelaksanaan prinsip akuntabilitas. Termasuk pula untuk meningkatkan kredibilitas penyampaian 


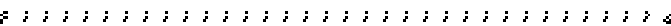

- Widya Akuntansi dan Keuangan

: Universitas Hindu Indonesia

Edisi Agustus 2020

pertanggungjawaban melalui LKPD (laporan keuangan pemda) dalam mewujudkan akuntabilitas dan transparansi pengelolaan keuangan daerah (Zulkarnain \& Ningrum, 2020).

Tuntutan terhadap kinerja dan pelaksanaan prinsip akuntabilitas kinerja berujung pada kebutuhan dilakukannya pengukuran kinerja pemda (Mustafa \& Halim, 2009). Pengukuran kinerja penting dilakukan untuk menilai akuntabilitas pejabat atau organisasi dalam menghasilkan layanan terbaik kepada publik, serta dalam mewujudkan good governance di pemda (Sartika, 2019).

Pengukuran kinerja juga perlu dilakukan untuk menjadi tolak ukur dalam upaya meningkatkan kinerja, diantaranya kinerja keuangan pemda pada periode berikutnya. Pengukuran kinerja keuangan pemda sangatlah penting, yang bertujuan membantu pemda menilai capaian suatu strategi atau evaluasi suatu program kegiatan melalui alat ukur (indikator) finansial (Mahmudi, 2016).

Provinsi Kalimantan Barat dikenal sebagai provinsi terluas keempat di Indonesia. Wilayah administrasi meliputi 14 (empat belas) Kabupaten/Kota dengan Ibukota Provinsi di Pontianak. Sebagai Ibukota Provinsi, Kota Pontianak memiliki keunggulan di bidang perdagangan dan jasa. Pusat-pusat perbelanjaan besar seperti mall dan pusat-pusat perbelanjaan medium lainnya berkembang pesat di Kota Pontianak (Pontianak, 2019b). Pusat-pusat pendidikan dan jasa lainnya juga mengalami hal yang serupa. Perguruan tinggi di Kota Pontianak menjadi incaran dari lulusan sekolah menengah dari seantero daerah di Kalimantan Barat untuk melanjutkan pendidikan tinggi, selain yang memilih melanjutkan pendidikan tinggi ke Pulau Jawa.

Hal tersebut setidaknya memberikan dampak pada lebih tingginya PAD Pemda Kota Pontianak dibanding daerah lainnya di Kalimantan Barat. Berdasarkan penelitian oleh Zulkarnain \& Andriansyah (2018), Pemda Kota Pontianak sebagai daerah yang memiliki kemandirian keuangan daerah tertinggi dibanding daerah lainnya di Kalimantan Barat. Sejak tahun 2012 sampai dengan tahun 2016 selalu terjadi peningkatan rasio kemandirian dari 23,96\% menjadi 37,83\% (Zulkarnain \& Andriansyah, 2018).

Pemerintah Kota (selanjutnya disingkat Pemkot) Pontianak pada awal tahun 2020, yaitu tepatnya pada tanggal 27 Januari 2020 di Bali, menerima penilaian dari Kementerian PANRB RI atas evaluasi penerapan SAKIP (Sistem Akuntabilitas Kinerja Instansi Pemerintah) pemerintah kabupaten/kota dengan menyandang Peringkat BB. Wakil Walikota Pontianak, Bahasan, dalam menanggapi capaian tersebut mengatakan bahwa predikat 


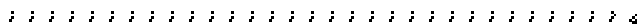

: Widya Akuntansi dan Keuangan

: Universitas Hindu Indonesia

Edisi Agustus 2020

tersebut menunjukkan efektivitas \& efisiensi dalam penggunaan anggaran di lingkungan Pemkot Pontianak, dan mencerminkan telah diselenggarakan dengan baik pemerintahan yang berorientasi pada hasil. Namun masih tetap memerlukan perbaikan yang lebih lanjut (Ibrahim, 2020).

Jauh sebelumnya, Pemkot Pontianak bersama Walikota Pontianak periode sebelumnya (Periode 2008-2018), Sutarmidji (Gubernur Kalimantan Barat saat ini), meraih segudang penghargaan (Syahroni \& Nasaruddin, 2017). Diantaranya sejak tahun 2011, LKPD (Laporan Keuangan Pemerintah Daerah) Kota Pontianak yang selalu mendapat predikat WTP dari BPK RI. Pada tahun 2015, Pemkot Pontianak mendapat anugerah sebagai Pemda dengan pelayanan publik terbaik di Indonesia oleh Ombudsman RI (Andilala \& Ratomo, 2016). Lalu penghargaan bergensi yang pernah diraih Sutarmidji adalah Walikota Terbaik Tahun 2017 oleh Kementerian Dalam Negeri RI (Murni \& Hairiadi, 2017).

Selanjutnya, penelitian ini berupaya untuk memberikan gambaran kinerja Pemkot Pontianak dari sisi keuangan. Beberapa penelitian sebelumnya menggunakan rasio keuangan daerah untuk menggambarkan kinerja keuangan pemda (Pilat \& Morasa, 2017), (Krisnaldy \& Deliana, 2018), (Sartika, 2019), dan (Zulkarnain, 2020). Diantaranya pula yang dilakukan di pemda pada wilayah yang sama yaitu di Kalimantan Barat (Mustafa \& Halim, 2009), (Zulkarnain \& Andriansyah, 2018), dan (Maulina \& Rhea, 2019) ataupun Kalimantan secara umum (Soeharjoto, 2019), namun belum ada yang khusus melakukan pada Pemkot Pontianak.

Alat ukur atau indikator rasio keuangan daerah yang digunakan dalam pengukuran kinerja keuangan Pemkot Pontianak kemudian menggunakan kombinasi dari alat ukur atau indikator yang digunakan oleh peneliti sebelumnya yaitu Mustafa \& Halim (2009), Sartika (2019), dan Zulkarnain (2020). Rasio keuangan daerah tersebut diantaranya, rasio derajat desentralisasi fiskal (DDF), rasio pertumbuhan PAD, rasio kontribusi pajak daerah \& retribusi daerah terhadap PAD, rasio ketergantungan keuangan pemerintah daerah, rasio efektivitas PAD, dan rasio belanja modal.

\section{METODE}

Penelitian dilakukan dengan menggunakan pendekatan kuantitatif yaitu dengan melakukan perhitungan pada data keuangan daerah yang diperoleh. Data dimaksud merupakan data yang bersifat historis, yakni data sekunder berupa Laporan Realisasi 
Anggaran Pemerintah Kota Pontianak tahun 2014-2018 yang dipublikasikan melalui laman web www.djpk.kemenkeu.go.id. Perhitungan data keuangan daerah dilakukan dengan rumus-rumus rasio keuangan sebagai berikut:

Tabel 1

\section{Rumus Rasio Keuangan}

\begin{tabular}{cccc}
\hline No. & Rumus Rasio Keuangan & \multicolumn{2}{c}{ Penjelasan Skala Interval } \\
\hline 1. & Derajat Desentralisasi Fiskal & $\%$ & Kemampuan Keuangan \\
\cline { 3 - 4 }$=$ & Total Realisasi PAD tahun $t$ & $0-10$ & Sangat Kurang \\
& Total Realisasi Pendapatan Daerah tahun $t$ & $20-30$ & Kurang \\
& & $30-40$ & Cukup \\
& & $40-50$ & Sedang \\
& & $>50$ & Baik \\
& & & Sangat Baik \\
\hline
\end{tabular}

2. Pertumbuhan PAD

$=\frac{\text { Total Realisasi PAD tahun } t}{\text { Total Realisasi PAD tahun } t-1}-1$

3. Kontribusi Pajak Daerah terhadap PAD

$=\frac{\text { Total Realisasi Pajak Daerah tahun } t}{\text { Total Realisasi PAD tahun } t}$

Kontribusi Retribusi Daerah terhadap PAD

$=\frac{\text { Total Realisasi Retribusi Daerah tahun } t}{\text { Total Realisasi PAD tahun } t}$

4. Ketergantungan Keuangan Pemda

$=\begin{array}{lcc}\text { Total Realisasi Pendapatan Transfer tahun t } & 25-50 & \text { Rendah } \\ \text { Total Realisasi Pendapatan Daerah tahun } t & 50-75 & \text { Sedang }\end{array}$

5. Efektivitas PAD

$=\frac{\text { Total Realisasi PAD tahun } t}{\text { Total Anggaran PAD tahun } t}$

$75-100 \quad$ Tinggi

\begin{tabular}{cc}
$\%$ & Kategori \\
\hline$<75$ & Tidak Efektif \\
$75-89$ & Kurang Efektif \\
$90-99$ & Cukup Efektif \\
100 & Efektif \\
$>100$ & Sangat Efektif
\end{tabular}

6. Rasio Belanja Modal

$=\frac{\text { Total Realisasi Belanja Modal tahun } t}{\text { Total Realisasi Belanja Daerah tahun } t}$

Sumber: UGM (1991), Mustafa \& Halim (2009), Sartika (2019), Zulkarnain (2020) 
Bentuk narasi secara deskriptif kemudian diterapkan untuk menggambarkan temuan dari hasil analisis data terkait. Untuk mencari sumber teori dan pelaksanaannya diperoleh dari riset pustaka dan penelitian sejenis yang dipublikasikan lewat jurnal penelitian.

\section{HASIL DAN PEMBAHASAN \\ Gambaran Umum Subjek Penelitian}

Kota Pontianak didirikan oleh Sultan Syarif Abdurrahman Alkadrie pada hari Rabu, 23 Oktober 1771. Kota Pontianak dikenal dengan sebutan Kota Khatulistiwa karena dilewati garis lintang 0 derajat. Di Siantan (sebelah utara Kota Pontianak) berdiri Tugu Khatulistiwa yang merupakan tonggak garis ekuator, dibangun oleh ahli geografi dari Belanda pada tahun 1928. Dua kali dalam setahun tepatnya pada tanggal 21 - 23 Maret, dan 21 - 23 September matahari siang akan berada tepat di atas kepala, sehingga membuat tugu serta benda di sekitarnya tidak memiliki bayangan (Pontianak, 2019b).

Berada atau dilewati oleh garis lintang $0^{0}$ membuat Kota Pontianak beriklim tropis, memiliki curah hujan yang cukup tinggi di antara 3.000-4.000 mm pertahun, dan terjadi pada bulan Mei sampai dengan Oktober, menyebabkan hutannya ditumbuhi berbagai pepohonan yang tumbuh subur. Suhu rata-rata Kota Pontianak antara $28^{0} \mathrm{C}-30^{0} \mathrm{C}$. Pada siang hari bahkan suhu bisa melebihi $32^{0} \mathrm{C}$ (Pontianak, 2019b).

Potensi komoditi unggulan Kota Pontianak adalah lidah buaya (aloe vera). Lidah buaya menjadi tanaman komoditi sejak pertama dikembangkan pada tahun 1980. Dalam beberapa tahun hingga 10 (sepuluh) tahun kemudian, dengan pembudidayaan yang lebih serius, masyarakat mendapatkan hasil yang menguntungkan. Lalu pada tahun 1992, potensi dari lidah buaya ini dan manfaat ekonomi yang dihasilkan disosialisasikan semakin masif. Pemkot Pontianak membangun Aloe Vera Center sebagai pusat pengembangan \& budi daya tanaman lidah buaya di bawah koordinasi Dinas Pertanian \& Kehutanan Kota Pontianak.

Kota Pontianak memiliki visi "Pontianak Kota Khatulistiwa, Berwawasan Lingkungan yang Cerdas dan Bermartabat". Saat ini Walikota Pontianak dijabat oleh Bapak Ir. H. Edi Rusdi Kamtono, M.M., M.T. dan Wakil Walikota Pontianak dijabat oleh Bapak Bahasan, S.H., yang merupakan pasangan terpilih dari Pilwako Pontianak tahun 2018 dengan raihan suara sebanyak 63,92\%, dan menjabat sejak 23 Desember 2018. 


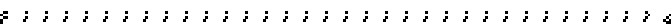

: Widya Akuntansi dan Keuangan

: Universitas Hindu Indonesia

Edisi Agustus 2020

Gambaran besar pengelolaan keuangan daerah Pemkot Pontianak, yang ditunjukkan dengan realisasi pendapatan dan belanja daerah, serta pembiayaan daerah tahun 2014-2018 sebagai berikut:

Tabel 2

Realisasi Pendapatan, Belanja, dan Pembiayaan Daerah Pemerintah Kota Pontianak Tahun 2014-2018

\begin{tabular}{lrrrrr}
\hline \multirow{2}{*}{ URAIAN } & \multicolumn{5}{c}{ TAHUN (Dalam Satuan Jutaan Rupiah) } \\
\cline { 2 - 6 } & \multicolumn{1}{c}{$\mathbf{2 0 1 8}$} & \multicolumn{1}{c}{$\mathbf{2 0 1 7}$} & $\mathbf{2 0 1 6}$ & \multicolumn{1}{c}{$\mathbf{2 0 1 5}$} & $\mathbf{2 0 1 4}$ \\
\hline PENDAPATAN DAERAH & $\mathbf{1 . 6 6 3 . 2 0 4}$ & $\mathbf{1 . 5 4 5 . 6 2 2}$ & $\mathbf{1 . 4 1 8 . 5 1 6}$ & $\mathbf{1 . 5 2 5 . 9 9 1}$ & $\mathbf{1 . 3 2 9 . 9 5 7}$ \\
Pendapatan Asli Daerah & 440.358 & 476.050 & 389.369 & 334.708 & 298.768 \\
Pendapatan Transfer & 1.158 .054 & 1.063 .062 & 1.022 .716 & 1.091 .057 & 1.030 .897 \\
Lain-Lain Pendapatan Yang Sah & 64.792 & 6.510 & 6.432 & 100.225 & 292 \\
BELANJA DAERAH & $\mathbf{1 . 6 0 5 . 7 1 9}$ & $\mathbf{1 . 5 1 2 . 4 7 6}$ & $\mathbf{1 . 4 2 8 . 9 1 8}$ & $\mathbf{1 . 4 9 8 . 7 1 6}$ & $\mathbf{1 . 3 2 6 . 3 5 1}$ \\
Belanja Operasi & 1.113 .213 & 1.060 .550 & 1.023 .525 & 1.034 .017 & 903.796 \\
Belanja Modal & 490.804 & 445.332 & 403.856 & 460.699 & 421.525 \\
Belanja Lain-lain & - & 277 & 220 & 2.683 & 2 \\
Transfer & 1.703 & 6.317 & 1.317 & 1.317 & 1.028 \\
SURPLUS/DEFISIT & $\mathbf{5 7 . 4 8 5}$ & $\mathbf{3 3 . 1 4 6}$ & $\mathbf{( 1 0 . 4 0 1 )}$ & $\mathbf{2 7 . 2 7 5}$ & $\mathbf{3 . 6 0 6}$ \\
PEMBIAYAAN DAERAH & $\mathbf{1 3 . 2 2 0}$ & $\mathbf{( 1 0 . 9 5 5 )}$ & $\mathbf{3 7 . 7 2 3}$ & $\mathbf{1 4 . 7 5 1}$ & $\mathbf{2 7 . 6 0 1}$ \\
Penerimaan Pembiayaan & 32.220 & 20.470 & 46.356 & 31.311 & 38.204 \\
Pengeluaran Pembiayaan & 19.000 & 31.425 & 8.633 & 16.561 & 10.604 \\
SiLPA & $\mathbf{7 0 . 7 0 5}$ & $\mathbf{2 2 . 1 9 1}$ & $\mathbf{2 7 . 3 2 2}$ & $\mathbf{4 2 . 0 2 6}$ & $\mathbf{3 1 . 2 0 6}$ \\
\hline
\end{tabular}

Sumber: www.djpk.kemenkeu.go.id, data update 28 Januari 2020 (diolah)

Tabel 2 di atas menunjukkan tren peningkatan tahun ke tahun pendapatan daerah dan belanja daerah Pemkot Pontianak. Pembangunan mengalami peningkatan yang cukup pesat di Kota Pontianak dalam 10 (sepuluh tahun) terakhir pada berbagai bidang, diantaranya pembangunan infrastruktur perkotaan, kesehatan, sarana dan prasarana pendidikan, serta sarana pelayanan publik lainnya (Kawilarang, 2019).

\section{Analisis Rasio Derajat Desentralisi Fiskal}

Rasio ini menggambarkan besar kemampuan daerah dalam membiayai Pengeluaran (Belanja) Daerah dari hasil pemungutan PAD. Berikut disajikan Rasio Derajat Desentralisasi Fiskal Pemkot Pontianak tahun 2014-2018: 
Tabel 3

Rasio Derajat Desentralisasi Fiskal (DDF) Pemerintah Kota Pontianak Tahun 2014-2018

\begin{tabular}{ccccc}
\hline TAHUN & PAD & $\begin{array}{c}\text { PENDAPATAN } \\
\text { DAERAH }\end{array}$ & DDF (\%) & $\begin{array}{c}\text { KEMAMPUAN } \\
\text { KEUANGAN }\end{array}$ \\
\hline 2014 & 298.768 .480 .275 & 1.329 .956 .797 .030 & $22,46 \%$ & Cukup \\
2015 & 334.708 .368 .452 & 1.525 .991 .158 .470 & $21,93 \%$ & Cukup \\
2016 & 389.368 .654 .493 & 1.418 .516 .388 .060 & $27,45 \%$ & Cukup \\
2017 & 476.050 .410 .314 & 1.545 .622 .287 .316 & $30,80 \%$ & Sedang \\
2018 & 440.358 .120 .031 & 1.663 .204 .429 .560 & $26,48 \%$ & Cukup \\
\hline Rata-rata & & & $\mathbf{2 5 , 8 2 \%}$ & Cukup \\
\hline
\end{tabular}

Sumber: www.djpk.kemenkeu.go.id, data update 28 Januari 2020 (diolah)

Tabel 3 di atas menunjukkan perkembangan DDF Pemkot Pontianak dalam lima tahun (2014-2018) berfluktuasi, namun relatif stabil. Secara rata-rata, DDF Pemkot Pontianak dalam periode penelitian berada pada kelompok "CUKUP", yang dapat diartikan kemampuan keuangan Pemkot Pontianak dalam membiayai penyelenggaraan pemerintahan dan pembangunan di daerah tergolong cukup oleh pembiayaan sendiri. Pemkot Pontianak terus melakukan berbagai upaya guna untuk meningkatkan penerimaan asli daerahnya dengan memperhatikan peran dunia usaha, serta iklim investasi yang kondusif maupun pertumbuhan ekonomi (Kawilarang, 2019).

\section{Analisis Rasio Pertumbuhan PAD}

Rasio ini menggambarkan besar kemampuan pemda untuk mempertahankan hingga meningkatkan keberhasilan pemungutan PAD dari periode ke periode. Berikut disajikan Rasio Pertumbuhan PAD Pemkot Pontianak tahun 2014-2018: 


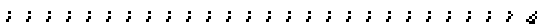

: Widya Akuntansi dan Keuangan

: Universitas Hindu Indonesia

Edisi Agustus 2020

Tabel 4

Rasio Pertumbuhan PAD

Pemerintah Kota Pontianak Tahun 2014-2018

\begin{tabular}{cccccc}
\hline TAHUN & Pajak Dae rah & $\begin{array}{c}\text { Retribusi } \\
\text { Daerah }\end{array}$ & $\begin{array}{c}\text { Hasil } \\
\text { Pengelolaan } \\
\text { Kky. Daerah }\end{array}$ & $\begin{array}{c}\text { Lain-lain } \\
\text { PAD yang } \\
\text { Sah }\end{array}$ & PAD \\
\hline 2014 & $13,09 \%$ & $-6,85 \%$ & $-56,75 \%$ & $78,23 \%$ & $12,63 \%$ \\
2015 & $18,35 \%$ & $-34,03 \%$ & $167,06 \%$ & $22,31 \%$ & $12,03 \%$ \\
2016 & $7,36 \%$ & $28,01 \%$ & $259,63 \%$ & $4,10 \%$ & $16,33 \%$ \\
2017 & $17,42 \%$ & $-15,13 \%$ & $-58,74 \%$ & $128,44 \%$ & $22,26 \%$ \\
2018 & $1,90 \%$ & $1,07 \%$ & $24,97 \%$ & $-37,12 \%$ & $-7,50 \%$ \\
\hline
\end{tabular}

Sumber: $\underline{w w w . d j p k . k e m e n k e u . g o . i d}$, data update 28 Januari 2020 (diolah)

Tabel 4 di atas menunjukkan tren positif peningkatan PAD secara total dari 2015-2017.

Bila dilihat berdasarkan komponen, antara tahun ke tahun tren peningkatan/penurunan sangat bervariatif, menunjukkan belum stabilnya capaian tiap komponen. Hal ini boleh jadi dikarenakan bergesernya berbagai kebijakan terkait penerapan pemungutan PAD antar komponen. Hal lain boleh jadi dikarenakan terdapat penerimaan yang sifatnya tentatif atau insidentil atau tidak rutin atau tidak berulang antara tahun ke tahun, contohnya pada komponen Lain-lain PAD yang Sah. Sedangkan untuk penerimaan PAD dari komponen Pajak Daerah kecenderungannya berulang dan mendapatkan penambahan tahun ke tahun.

\section{Analisis Rasio Kontribusi Pajak Daerah \& Retribusi Daerah Terhadap PAD}

Rasio ini menggambarkan besar sokongan atau sumbangan atau andil dari pembayaran pajak daerah masyarakat maupun pembayaran retribusi daerah atas penerimaan PAD secara keseluruhan. Berikut disajikan Rasio Kontribusi Pajak Daerah \& Retribusi Daerah terhadap PAD Pemkot Pontianak tahun 2014-2018:

Tabel 5

Rasio Kontribusi Pajak Daerah \& Retribusi Daerah Terhadap PAD Pemerintah Kota Pontianak Tahun 2014-2018

\begin{tabular}{|c|c|c|c|c|c|}
\hline \multirow{2}{*}{ TAHUN } & \multicolumn{2}{|c|}{ Pajak Daerah } & \multicolumn{2}{|c|}{ Retribusi Dae rah } & \multirow{2}{*}{ PAD } \\
\hline & Jumlah & $\%$ & Jumlah & $\%$ & \\
\hline 2014 & 203.165 .655 .899 & $68,00 \%$ & 49.752 .244 .887 & $16,65 \%$ & 298.768 .480 .275 \\
\hline 2015 & 240.452 .113 .349 & $71,84 \%$ & 32.821 .997 .143 & $9,81 \%$ & 334.708 .368 .452 \\
\hline 2016 & 258.149.996.119 & $66,30 \%$ & 42.016 .145 .122 & $10,79 \%$ & 389.368 .654 .493 \\
\hline 2017 & 303.127.995.782 & $63,68 \%$ & 35.657 .077 .655 & $7,49 \%$ & 476.050.410.314 \\
\hline 2018 & 308.900.825.494 & $70,15 \%$ & 36.039 .842 .255 & $8,18 \%$ & 440.358 .120 .031 \\
\hline Rata-rata & & $67,99 \%$ & & $10,58 \%$ & \\
\hline
\end{tabular}

Sumber: www.djpk.kemenkeu.go.id, data update 28 Januari 2020 (diolah) 


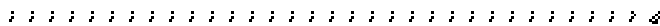

- Widya Akuntansi dan Keuangan

: Universitas Hindu Indonesia

Edisi Agustus 2020

Tabel 5 di atas menunjukkan peran yang besar dari komponen pajak daerah menyumbang penerimaan PAD secara keseluruhan dari tahun ke tahun. Jenis pajak daerah yang memberikan kontribusi besar dalam pembentukan kumulatif pajak daerah adalah dari BPHTB, Pajak Penerangan Jalan, dan Pajak Restoran. Hal ini tidak terlepas dari topangan sektor pariwisata, diantaranya kuliner, yang semakin menggeliat di Kota Pontianak. Kuliner Kota Pontianak seperti ikan asam pedas, mie kepiting, bubur pedas, mie sagu, kerupuk basah, dan sotong pangkong sangat disenangi dan banyak diincar oleh wisatawan yang berkunjung ke Kota Pontianak, baik wisatawan nusantara maupun wisatawan mancanegara (Pontianakpost, 2020).

Sedangkan jenis retribusi daerah yang memberikan kontribusi besar dalam pembentukan kumulatif retribusi daerah adalah dari retribusi (jasa umum) pelayanan persampahan, retribusi (perizinan tertentu) izin mendirikan bangunan, dan retribusi (jasa usaha) pemakaian kekayaan daerah. Ketiga hal ini kembali menunjukkan Kota Pontianak sebagai daerah yang membangun, dengan aktivitas usaha atau berjualan yang marak berkembang di masyarakat.

\section{Analisis Rasio Ketergantungan Keuangan Pemerintah Daerah}

Rasio ini menggambarkan besar ketergantungan pemda terhadap sumber penerimaan daerah dari pendapatan transfer, baik transfer pemerintah pusat maupun transfer antar daerah. Berikut disajikan Rasio Ketergantungan Keuangan Pemerintah Daerah Pemkot Pontianak tahun 2014-2018:

Tabel 6

\section{Rasio Ketergantungan Keuangan Pemerintah Daerah Pemerintah Kota Pontianak Tahun 2014-2018}

\begin{tabular}{ccccc}
\hline TAHUN & $\begin{array}{c}\text { PENDAPATAN } \\
\text { TRANSFER }\end{array}$ & $\begin{array}{c}\text { PENDAPATAN } \\
\text { DAERAH }\end{array}$ & $\%$ & $\begin{array}{c}\text { KETERGANTU- } \\
\text { NGAN }\end{array}$ \\
\hline 2014 & 1.030 .896 .782 .115 & 1.329 .956 .797 .030 & $77,51 \%$ & Tinggi \\
2015 & 1.091 .057 .400 .656 & 1.525 .991 .158 .470 & $71,50 \%$ & Sedang \\
2016 & 1.022 .715 .733 .567 & 1.418 .516 .388 .060 & $72,10 \%$ & Sedang \\
2017 & 1.063 .061 .877 .003 & 1.545 .622 .287 .316 & $68,78 \%$ & Sedang \\
2018 & 1.158 .053 .989 .529 & 1.663 .204 .429 .560 & $69,63 \%$ & Sedang \\
\hline Rata-rata & & & $\mathbf{7 1 , 9 0 \%}$ & Sedang \\
\hline
\end{tabular}

Sumber: www.djpk.kemenkeu.go.id, data update 28 Januari 2020 (diolah) 
isididizizo

- Widya Akuntansi dan Keuangan

: Universitas Hindu Indonesia

Edisi Agustus 2020

Tabel 6 di atas menunjukkan ketergantungan keuangan Pemkot Pontianak akan transfer dari pemerintah pusat dan transfer dari daerah lainnya secara rata-rata masuk kategori "SEDANG". Adapun jenis transfer terbesar dari pemerintah pusat yaitu dari transfer Dana Alokasi Umum yang selama lima tahun periode penelitian mencapai 42,05\% - 50,38\% dari total Pendapatan Daerah tiap tahun, atau mencapai $60,40 \%$ - 69,61\% dari total pendapatan transfer.

\section{Analisis Rasio Efektivitas PAD}

Rasio ini menggambarkan kemampuan pemda untuk merealisasikan target PAD di dalam APBD. Berikut disajikan Rasio Efektivitas PAD Pemkot Pontianak tahun 2014-2018:

Tabel 7

Rasio Efektivitas PAD

Pemerintah Kota Pontianak Tahun 2014-2018

\begin{tabular}{crrcc}
\hline TAHUN & TARGET PAD & REALISASI PAD & $\%$ & $\begin{array}{c}\text { KETERGANTU- } \\
\text { NGAN }\end{array}$ \\
\hline 2014 & 43.791 .732 .000 & 298.768 .480 .275 & $682,25 \%$ & Sangat Efektif \\
2015 & 351.842 .687 .997 & 334.708 .368 .452 & $95,13 \%$ & Cukup Efektif \\
2016 & 378.675 .094 .000 & 389.368 .654 .493 & $102,82 \%$ & Sangat Efektif \\
2017 & 412.594 .897 .413 & 476.050 .410 .314 & $115,38 \%$ & Sangat Efektif \\
2018 & 469.112 .615 .373 & 440.358 .120 .031 & $93,87 \%$ & Cukup Efektif \\
\hline Rata-rata & & & $\mathbf{2 1 7 , 8 9 \%}$ & Sangat Efektif \\
\hline
\end{tabular}

Sumber: www.djpk.kemenkeu.go.id, data update 28 Januari 2020 (diolah)

Tabel 7 di atas menunjukkan telah efektifnya pencapaian realisasi target PAD Pemkot Pontianak. Hal ini tidak terlepas dari peran masyarakat Kota Pontianak yang taat dalam membayar pajak (Syahroni \& Jamadin, 2018). Termasuk pula upaya Pemkot Pontianak dengan memasang tapping box di tempat usaha untuk mendorong pemilik usaha selaku wajib pajak taat membayar pajak (Pontianak, 2019a).

\section{Analisis Rasio Belanja Modal}

Rasio ini menggambarkan besar pengeluaran pemerintah untuk pengadaan aset tetap yang dapat memberi manfaat dalam lebih dari satu tahun anggaran. Jenis pengadaan aset tetap meliputi pertama, pengadaan aset tetap yang dapat dirasakan langsung manfaatnya oleh masyarakat, seperti untuk pembangunan jalan, sekolah, rumah sakit, dan seterusnya. Kedua, pengadaan aset tetap yang secara langsung tidak dirasakan manfaatnya oleh masyarakat, 


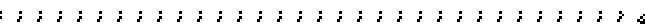

: Widya Akuntansi dan Keuangan

: Universitas Hindu Indonesia

Edisi Agustus 2020

yaitu untuk menunjang operasional kegiatan pemerintahan, seperti untuk pembangunan gedung pemerintahan, kendaraan dinas operasional, dan seterusnya. Berikut disajikan Rasio Belanja Modal Pemkot Pontianak tahun 2014-2018:

\section{Tabel 8}

\section{Rasio Belanja Modal}

Pemerintah Kota Pontianak Tahun 2014-2018

\begin{tabular}{cccc}
\hline TAHUN & $\begin{array}{c}\text { BELANJA } \\
\text { MODAL }\end{array}$ & $\begin{array}{c}\text { BELANJA } \\
\text { DAERAH }\end{array}$ & $\%$ \\
\hline 2014 & 421.525 .162 .769 & 1.326 .351 .108 .689 & $31,78 \%$ \\
2015 & 460.699 .261 .845 & 1.498 .715 .869 .038 & $30,74 \%$ \\
2016 & 403.855 .553 .578 & 1.428 .917 .646 .777 & $28,26 \%$ \\
2017 & 445.331 .701 .910 & 1.512 .476 .062 .494 & $29,44 \%$ \\
2018 & 490.804 .054 .138 & 1.605 .719 .399 .876 & $30,57 \%$ \\
\hline Rata-rata & & & $\mathbf{3 0 , 1 6 \%}$ \\
\hline
\end{tabular}

Sumber: www.djpk.kemenkeu.go.id, data update 28 Januari 2020 (diolah)

Tabel 8 di atas menunjukkan cukup besarnya rasio belanja modal di Pemkot Pontianak, yaitu mencapai rata-rata 30,16\%. Jumlah ini telah melebihi rata-rata belanja modal di pemda (Mahmudi, 2016). Sebagai perbandingan, pemda kabupaten/kota di Jawa Barat yang memiliki rasio belanja modal tertinggi di tahun 2018 adalah Pemkot Depok, dengan rasio belanja modal sebesar 27,86\% (Zulkarnain, 2020).

\section{SIMPULAN}

Berdasarkan hasil analisis rasio keuangan di atas, dapat ditarik beberapa simpulan terkait kinerja keuangan Pemkot Pontianak, diantaranya: (1) kemampuan keuangan Pemkot Pontianak dalam membiayai penyelenggaraan pemerintahan dan pembangunan di daerah tergolong cukup oleh pembiayaan sendiri; (2) penerimaan PAD menunjukkan tren positif terjadi peningkatan antara tahun ke tahun khususnya dari komponen pajak daerah; (3) kontribusi pajak daerah dalam menyumbang penerimaan PAD secara keseluruhan sangat besar mencapai 68\%; (4) ketergantungan keuangan Pemkot Pontianak akan transfer dari pemerintah pusat dan daerah lainnya termasuk kategori "sedang". Jenis transfer terbesar dari pemerintah pusat yaitu DAU; (5) pencapaian realisasi target PAD Pemkot Pontianak tergolong sangat efektif, yang tidak terlepas dari peran masyarakat dengan taat dalam membayar pajak; dan (6) rasio belanja modal di Pemkot Pontianak telah melebihi rata-rata rasio belanja modal di pemerintahan daerah, yaitu mencapai 30,16\%. Rasio ini bahkan lebih 


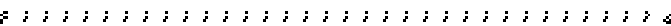

: Widya Akuntansi dan Keuangan

: Universitas Hindu Indonesia

Edisi Agustus 2020

besar dari Pemda Kabupaten/Kota di Jawa Barat yang memiliki rasio belanja modal tertinggi di tahun 2018 yaitu Pemkot Depok dengan rasio belanja modal sebesar 27,86\%.

Penelitian ini memiliki keterbatasan pada kedalaman pengkajian, dalam mengutarakan informasi kualitatif yang bersumber langsung dari pihak Pemkot Pontianak. Penelitian berikutnya dapat mempertimbangkan untuk menggali informasi tersebut, misalnya langsung dari Pejabat Pengelola Keuangan Daerah pemda setempat.

\section{DAFTAR RUJUKAN}

Andilala, \& Ratomo, U. T. (2016). Pontianak Raih Penghargaan Pelayanan Publik Terbaik se-Indonesia.

Antaranews.Com. https://www.antaranews.com/berita/600527/pontianak-raih-penghargaan-pelayananpublik-terbaik-se-indonesia

Fardianti, A. N. (2018). Analisis Rasio Keuangan Pemerintah Daerah: Studi Kasus pada Pemerintah Daerah Kota Bandung tahun 2011-2016. UIN Sunan Gunung Djati Bandung.

Ibrahim, J. (2020). Pemkot Pontianak Pertahankan SAKIP Predikat BB. Pontianakkota.Go.Id. https://www.pontianakkota.go.id/pontianak-hariini/berita/Pemkot-Pontianak-Pertahankan-SAKIP-Predikat-BB

Kawilarang, R. R. A. (2019). APBD 2020, Pontianak Targetkan Pendapatan Rp1,89 Triliun. Viva.Co.Id. https://www.viva.co.id/berita/nasional/1245743-apbd-2020-pontianaktargetkan-pendapatan-rp1-89-triliun

Krisnaldy, K., \& Deliana, M. (2018). Analisis Rasio Keuangan APBD Provinsi DKI Jakarta. KREATIF: Jurnal Ilmiah Prodi Manajemen Universitas Pamulang, 6(3), 49-58.

Mahmudi. (2016). Analisis Laporan Keuangan Pemerintah Daerah. UPP STIM YKPN.

Maulina, F., \& Rhea, R. (2019). Analisis Rasio Keuangan untuk Mengukur Kinerja Keuangan Pemerintah Daerah (Studi Kasus pada Pemerintah Provinsi Kalimantan Barat). Obis, 2(1), 11-22.

Murni, M., \& Hairiadi, A. (2017). Sutarmidji Dinobatkan Sebagai Wali Kota Terbaik se Indonesia. Equator.Co.Id. https://equator.co.id/sutarmidji-dinobatkan-sebagai-walikota-terbaik-se-indonesia/

Mustafa, B., \& Halim, A. (2009). Pengukuran Kinerja Dinas Pendapatan Daerah Provinsi Kalimantan Barat. Jurnal Aplikasi Manajemen, 7(4), 792-802.

Novitasari, Y., \& Hapitri, D. (2019). Realisasi Belanja Pemerintah Sektor Kesehatan dan Pendidikan, serta Pengaruhnya Terhadap IPM Kabupaten/Kota di Jawa Barat. Cakrawala, 2(1), 1-15.

Nurdiwaty, D., \& Zaman, B. (2016). Analisis Rasio Keuangan Daerah untuk Menilai Kinerja Keuangan Daerah (Studi Kasus pada Dinas Pendapatan Pengelolaan Keuangan dan Aset Kota Kediri). Journal of Innovation in Business and Economics, 7(1), 31-40. 
Pilat, J. J., \& Morasa, J. (2017). Analisis Rasio Keuangan Anggaran Pendapatan dan Belanja Daerah (APBD) Kota Manado untuk Menilai Kinerja Keuangan Pemerintah Kota Manado Tahun Anggaran 2011-2015. Jurnal Accountability, 6(1), 45-56.

Pontianak, P. K. (2019a). Pemasangan Tapping Box Dongkrak Pendapatan Daerah. Pontianakkota.Go.Id. https://www.pontianakkota.go.id/pontianak-hariini/berita/Pemasangan-Tapping-Box-Dongkrak-Pendapatan-Daerah

Pontianak, P. K. (2019b). Potensi Pemerintah Kota Pontianak. Pontianakkota.Go.Id. https://www.pontianakkota.go.id/tentang/potensi

Pontianakpost. (2020). Kembangkan Potensi Kuliner Daerah. Pontianakpost.Co.Id. https://pontianakpost.co.id/kembangkan-potensi-kuliner-daerah/

Sartika, N. (2019). Analisis Rasio Keuangan Daerah untuk Menilai Kinerja Keuangan Pemerintah Daerah Kepulauan Meranti. Inovbiz: Jurnal Inovasi Bisnis, 7(2), 147-153.

Soeharjoto, S. (2019). Kemampuan dan Kinerja Keuangan Provinsi Kalimantan. Akuntabel, 15(2), 131-138.

Syahroni, \& Jamadin. (2018). Edi Kamtono: Pembangunan Kota Pontianak Tak Terlepas Peran Masyarakat Bayar Pajak. Pontianak.Tribunnews.Com. https://pontianak.tribunnews.com/2018/11/07/edi-kamtonopembangunan-kotapontianak-tak-terlepas-peran-masyarakat-bayar-pajak

Syahroni, \& Nasaruddin. (2017). Setahun Raih 32 Penghargaan Bergengsi, Sutarmidji Sebut 1 Penghargaan Ini Bikin Pontianak Bangga. Pontianak.Tribunnews.Com. https://pontianak.tribunnews.com/2017/11/19/setahun-raih-32-penghargaanbergengsi-sutarmidji-sebut-1-penghargaan-ini-bikin-pontianak-bangga

UGM, F. (1991). Pengukuran Kemampuan Keuangan Daerah dalam Rangka Pelaksanaan Otonomi Daerah yang Nyata dan Bertanggung Jawab. In Laporan Akhir Penelitian.

Zulkarnain, Z. (2020). Analisis Rasio Keuangan Daerah untuk Mengukur Kinerja Keuangan Pemerintah Kabupaten-Kota di Jawa Barat. Cakrawala, 3(1), 61-74.

Zulkarnain, Z., \& Andriansyah, R. (2018). Opini Audit BPK-RI dan Substansi Kinerja Keuangan Pemerintah Daerah Kota/Kabupaten di Provinsi Kalimantan Barat. Cakrawala, 1(1), 58-74.

Zulkarnain, Z., \& Ningrum, D. A. (2020). Determinan Kualitas Laporan Keuangan Pemerintah Daerah Kota Sukabumi. Syntax Literate: Jurnal Ilmiah Indonesia, 5(5), 197-211. https://doi.org/10.36418/syntax-literate.v5i5.1161 